Corinna A. Jerkin

Sveučilište u Zagrebu

Filozofski fakultet

Poslijediplomski doktorski studij kroatistike

corinna.jerkin@yahoo.com

\section{Maja G. Opašić}

Sveučilište u Rijeci

Učiteljski fakultet

Katedra za metodike nastavnih predmeta

humanističkih znanosti i umjetnosti

mopasic@uniri.hr

\title{
SLUČAJ SLIKOVNICE: \\ POLOŽAJ SLIKOVNICE U HRVATSKIM ODGOJNO-OBRAZOVNIM DOKUMENTIMA ${ }^{1}$
}

\begin{abstract}
APSTRAKT: Polazeći od teze o slučaju dječje književnosti koja se odnosi na prešućivanje i zanemarivanje dječje književnosti u okviru teorije književnosti i akademske zajednice u cjelini, u radu se razvija i ispituje teza o slučaju slikovnice u odgojno-obrazovnome kontekstu. Analiziraju se važeći odgojno-obrazovni dokumenti u Hrvatskoj u usporedbi s onima koji su donedavno bili na snazi da bi se utvrdila pojavnost slikovnice po odgojnoobrazovnim ciklusima ili razredu, zastupljenost slikovničkih sadržaja u odgojnoobrazovnim područjima i nastavnim predmetima, osobito u Hrvatskome jeziku i posebno u lektiri te pristupi slikovnici u okviru pojedinih odgojno-obrazovnih područja. Rezultati analize pokazuju da ni u reformskim dokumentima nije prepoznat potencijal slikovnice na koji ukazuju suvremena teorijska i metodička promišljanja. Slikovnica je i dalje prisutna uglavnom na početnim obrazovnim razinama, a opcionalne i preopćenite smjernice za uvođenje u nastavnu praksu ne osiguravaju joj stvarnu zastupljenost te dostatno i standardizirano produbljivanje spoznaja.
\end{abstract}

Ključne riječi: dječja književnost, Engleski jezik, Hrvatski jezik, kurikul, Likovna kultura, nastavni plan i program, (rani) književni odgoj, slikovnica.

\section{THE CASE OF PICTUREBOOK: PICTUREBOOK PRESENCE IN CROATIAN EDUCATIONAL DOCUMENTS}

ABSTRACT: On the basis of the case of children's literature, which points to its concealment and neglect within the literary theory and academic community as a whole, the

\footnotetext{
${ }^{1}$ Ovaj je rad financiralo Sveučilište u Rijeci projektom uniri-pr-human-19-9.
} 
paper develops and examines picturebooks in the educational context. Current educational documents in Croatia are analyzed and compared to those in force until recently to determine the presence of picturebooks by educational cycle or grade. Furthermore, the representation of picturebook content in educational areas and subjects, particularly in the subject Croatian Language and especially in required reading lists, is analyzed, including the approaches to picturebooks within particular educational areas. The results indicate that the potential of picturebooks remains unrecognized even in the reform documents, as indicated by contemporary theoretical and pedagogical considerations. Picturebooks remain present mainly at the initial educational levels, while optional and overly generalized guidelines for their introduction into the teaching practice do not ensure their genuine representation and sufficient and standardized deepening of knowledge.

Key words: children's literature, English Language, Croatian Language, curriculum, Arts, syllabus, (early) literary education, picturebook.

\section{UVOD}

Slikovnica je, iz kanonske perspektive, dvostruko marginalizirana kao niži oblik nižega oblika književne umjetnosti (dječje književnosti) ${ }^{2}$. Naime, i u okviru dječje književnosti ponekad je prihvaćen stav da je slikovnica namijenjena najmlađim čitateljima i prema tome na neki način jednostavnija od romana (Hateley 2018), a sama dječja književnost već je marginalizirana u okviru znanosti o književnosti, što je primijećeno u inozemnoj i domaćoj zajednici istraživača dječje književnosti. Zohar Shavit (1994) prozvala ju je Pepeljugom znanosti o književnosti, pronalazeći uzroke nepovoljna, odnosno podređena položaja njezina istraživanja u nastojanjima da se razmatranja dječje književnosti uklope $u$ tradicionalna proučavanja književnosti. Deborah Thacker (2000) promotrila je odsutnost dječje književnosti iz književne teorije pitajući se je li riječ o prijeziru ili neznanju. Smiljana Narančić Kovač (2012) ispitala je teorijski status dječje književnosti u kontekstu opreke visoko - nisko u književnosti i kulturi, pri čemu je neopravdanu pojavu prešućivanja i zanemarivanja dječje književnosti u okviru teorije književnosti, ali i u akademskoj zajednici uopće nazvala slučajem dječje književnosti.

${ }^{2}$ Slikovnica je poseban sintetski medij i vrsta umjetnosti (Nikolajeva 2002: 85, Narančić Kovač 2015: 32), a ne žanr ili vrsta dječje književnosti, poput primjerice bajke ili priče o životinjama jer slikovnice mogu činiti neke od tih vrsta (Narančić Kovač 2015: 54). Ipak, slikovnica je nesumnjivo povezana s dječjom književnosti i na nju se gleda(lo) i kao na djelo dječje književnosti (v. u Narančić Kovač 2015: 52-54). Zatim, nije samo slikovnica zapostavljena u dječjoj književnosti. I dječji igrokaz zadobio je epitet zapostavljenoga književnog žanra u teoriji hrvatske dječje književnosti (Verdonik i Štiglić 2015), a valja primijetiti da su obje vrste hibridne (sintetske), književna i vizualna, odnosno scenska. 
Slikovnica je nedvojbeno, kao što je to istaknuto i u naslovu simpozija održanoga 1971. u Zagrebu, prva djetetova knjiga (Slikovnica prva knjiga djeteta 1972), ali neopravdano je zadobila etiketu isključivo prve djetetove knjige (usp. Bukvić 2019). Za razliku od uvriježenoga javnog mišljenja, suvremena slikovnička istraživanja opovrgavaju pogrešnu predodžbu o slikovnici kao knjizi rezerviranoj samo za najmlađe čitatelje i njima je slikovnica prepoznata kao posebna umjetnička vrsta ${ }^{3}$ namijenjena ukriženoj (crossover) publici djece i odraslih ili ljudima svake dobi (usp. Beckett 2012, Narančić Kovač 2015). Drugim riječima, „slikovnica nije tek puki uvod u književnost ili druge medije kao jednostavniji oblik pripovijedanja ili posredovanja informacija. Naprotiv, dobra slikovnica obiluje sofisticiranim značenjima i načinima izražavanja" (Narančić Kovač 2019a: 342 ).

U suvremenim se znanstvenim publikacijama posvećenim slikovnici ističe razvoj slikovnice kao umjetničke vrste i procvat znanstvenih istraživanja u novije vrijeme. Pritom je primijećeno da je istraživanje slikovnice doživjelo znakovite promjene krajem 20. stoljeća. U početku su dominirale povijesne perspektive i teme pojave i razvoja slikovnice, zatim su se slikovnice promatrale kao umjetnički oblik (vrsta) ili obrazovno sredstvo za usvajanje jezika, uvod u književnost i vizualnu pismenost, a posljednjih godina zadobile su teorijsku pozornost (Colomer, Kümmerling-Meibauer i Silva-Díaz 2010: 1).

Razvoj istraživanja slikovnice u Hrvatskoj prikazala je Narančić Kovač (2015: 35-39). Ustvrdila je da su i u nas povijesna, pedagoška i metodička proučavanja prethodila teorijskim razmatranjima za koje je istaknula da su, za razliku od ostalih pristupa, ,još na samome početku” (2015: 37).

Polazeći od činjenice da dječja književnost kao sustav pripada i književnomu i obrazovnomu sustavu (Shavit 1994: 4) i slučaja dječje književnosti, prema kojemu teorijski rezultati obično ostaju u zatvorenome krugu istraživača dječje književnosti (Narančić Kovač 2015: 644), cilj je ovoga rada utvrditi odražava li se u donedavnim i aktualnim hrvatskim odgojno-obrazovnim dokumentima slučaj slikovnice.

Pod slučajem slikovnice podrazumijeva se podređen i neprikladan položaj koji slikovnica uživa u određenome kontekstu, u ovome slučaju odgojno-

\footnotetext{
${ }^{3}$ U podnaslovu knjige Crossover Picturebooks S. Beckett stoji engleski naziv genre, a odgovarajuće hrvatsko nazivlje nije usustavljeno. Terminološku zbrku u vezi s nazivima žanr i vrsta prikazale su Bačić-Karković i Car-Mihec (usp. 2000: 17-18), a ona se ogleda i u uporabi naziva u radovima iz dječje književnosti.
} 
-obrazovnome. Slučaj slikovnice temelji se na slučaju dječje književnosti i marginalizacije slikovnice kao vrste namijenjene isključivo najmlađoj publici, a dijelom proizlazi iz nedovoljne upućenosti predmetnih učitelja i nastavnika u srednjim školama $u$ teorijska, povijesna i metodička razmatranja slikovnice. Naime, na hrvatskim sveučilištima nemalo je kolegija posvećeno isključivo slikovnici ${ }^{4}$, i to samo na učiteljskim fakultetima, a čak ni kolegiji dječje književnosti nisu obvezni na svim studijima na kojima se obrazuju budući učitelji i nastavnici ponajprije Hrvatskoga jezika. ${ }^{5}$ Osim toga, realno je pretpostaviti da nedovoljno poznaju slikovničke naslove kad je istraživanjem to utvrđeno za dječje knjižničare (usp. Martinović i Stričević 2013).

Prema tome, u ovome radu propituje se uvažavaju li se suvremene teorijske spoznaje o slikovnici u preporukama za rad sa slikovnicom u procesu odgoja, učenja i poučavanja ili ih sastavljači ne ugrađuju u odgojno-obrazovne dokumente jer ih nedovoljno poznaju ili im pridaju manju važnost u odnosu na druge sastavnice (sadržaje, ishode).

\section{SLIKOVNICA U DJEČJEM VRTIĆU I ŠKOLI: UVIDI I MOGUĆNOSTI}

U ovome poglavlju izdvojeni su podatci i spoznaje iz metodičkih razmatranja slikovnice $\mathrm{u}$ (ranome) književnom odgoju u svrhu pružanja uvida $\mathrm{u}$ donedavnu i trenutačnu situaciju te su opisane mogućnosti unapređenja metodičke prakse u skladu sa suvremenim spoznajama.

Haramija (2004) je primijetila da je u slovenskome vrtićkom kurikulu književnost neopravdano pridružena samo jezičnom odgoju, kao njegov svojevrsni privjesak, a nije prepoznata kao zasebna umjetnost. ${ }^{6}$ Neuvrštavanjem književnosti u umjetničko područje njezini ciljevi nisu posebno razvijeni, već su uklopljeni u opće ciljeve i ciljeve jezičnoga odgoja, pri čemu su u manjini i u određenome

4 Izborni kolegij Slikovnica - prva knjiga djeteta izvodi se na preddiplomskome sveučilišnom studiju Rani i predškolski odgoj i obrazovanje na Učiteljskome fakultetu u Rijeci, a kolegij Slikovnica na engleskome jeziku obvezan je kolegij na Integriranome preddiplomskome i diplomskome sveučilišnom učiteljskom studiju, smjer Engleski jezik na zagrebačkome Učiteljskom fakultetu.

${ }^{5}$ Primjerice, na studiju Kroatistike na Filozofskome fakultetu u Zagrebu kolegij o hrvatskoj dječjoj književnosti nudi se samo na jednopredmetnome studiju na preddiplomskoj razini kao izborni. Podrobnu analizu prisutnosti kolegija posvećenih dječjoj književnosti na hrvatskim sveučilištima provela je Narančić Kovač (2020).

${ }^{6}$ Maćehinski odnos prema književnosti u kurikulnome kontekstu kritizirao je i Rosandić (2010: 11). 
smislu podređeni. Odgojitelji bi trebali uravnoteženo provoditi sva kurikulna područja, no u praksi se često događa da preteže područje koje je pojedinomu odgojitelju bliže, stoga Haramija predlaže nastavni program koji bi propisivao određene književne vrste za pojedinu dob, ali dopuštao odgojiteljima slobodan odabir naslova. Predstavila je i nepovoljne rezultate do kojih su došli diplomanti: kutići knjiga često nemaju dostatan broj naslova ili su knjige stare i poderane i odgojitelji nedovoljno upućuju na njih. Zatim, uočena je nelogičnost $u$ ispunjenim upitnicima. Odgojitelji tvrde da se kvalitetno pripremaju za posredovanje književnih djela, no istovremeno priznaju da često čitaju knjige koje djeca donose od kuće i traže da im se pročitaju u vrtiću, dakle bez postavljenih ciljeva, prethodnoga čitanja i povezivanja s drugim kurikulnim područjima. Autorica je upozorila $i$ na to da $u$ dječjim vrtićima treba njegovati literarno-estetsku $i$ pragmatičnu vrstu čitanja te da odgojitelji trebaju birati slikovnice kvalitetnoga teksta i ilustracija. Istaknula je da su slušanje, pripovijedanje i kasnije čitanje osnovne sastavnice uspješnoga ranog knjižnog odgoja.

Slunjski (2006) je na temelju provedenih istraživanja zaključila da u mnogim hrvatskim ustanovama ranoga i predškolskoga odgoja prevladava tradicionalni metodički pristup književnim tekstovima, odnosno da se obrađuju kao u školi. Takav je pristup, koji podrazumijeva odabir istoga sadržaja za svu djecu, provođenje aktivnosti kao obvezne u određenome vremenu te čiji je cilj upamćivanje i reproduciranje (npr. krasnoslov) ocijenila neprimjerenim jer ne uvažava potrebe i mogućnosti svakoga djeteta. Iako su primjedbe u određenoj mjeri osnovane, ne može se oštro odijeliti tradicionalni od suvremenoga metodičkoga pristupa, a tradicionalno nije po sebi loše i neprikladno danas. Primjedba koju upućuje Slunjski u vezi s okupljanjem djece radi vođene književne aktivnosti ne stoji u potpunosti. Djecu se u aktivnostima prekida i primjerice za ručak. Dakako, djecu ne treba prisiljavati na sudjelovanje u određenoj aktivnosti, već ih motivirati na uključivanje. Upamćivanje i reprodukcija književnih tekstova, jasno, ne smiju biti isključivi cilj, ali njihovo kazivanje ima pozitivne učinke, primjerice mogu „,pospješiti recepciju jezika te olakšati usvajanje materinskoga jezika u ranojezičnoj fazi” (Pavličević-Franić 2005: 243).

Velički (2009) je, za razliku od Slunjski, primijetila izbacivanje okupljanja iz metodičke prakse, a upravo u okupljanju radi druženja, ,razgovaranja, čitanja i slušanja priča i stihova, igranja gestovnih i pokretnih igara te igara za poticanje govornog stvaralaštva" (85) vidi priliku za poticanje govorne kompetencije u kontekstu zadovoljenja dječjih potreba. 
Martinović (2011) je istražila slikovnicu kao poticajni materijal za leksički razvoj djece u trećoj godini. Korpus čine slikovnice objavljene u Hrvatskoj 2007. 2009., a rezultati pokazuju da se slikovnice znatno razlikuju s obzirom na veličinu i raznolikost zastupljenoga rječnika te ukazuju na nesklad raznolikosti rječnika slikovnica te rječnika djece određene dobi kojoj su slikovnice namijenili nakladnici i knjižničari.

Skladany (2018) je, anketirajući odgojitelje doznala da često, gotovo svakodnevno, čitaju djeci, individualno, u manjim skupinama ili svima, međutim najčešće biraju poučne bajke i basne te problemske, edukativne, tematske i terapijske slikovnice koje sadržajno odgovaraju stvarnomu problemu u skupini. Istraživanjem je otkriveno i da se neki odgojitelji ne pripremaju za čitanje, što je problematizirala i Haramija (2004).

Neira-Piñeiro i Martín-Macho Harrison (2020) u istraživanju o izboru tekstova za književni odgoj i poticanje čitanja među studentima predškolskoga odgoja na dvama španjolskim sveučilištima utvrdile su da mnogi studenti nemaju razvijene kriterije za procjenjivanje prikladnosti književnih djela dječjoj publici te da je njihovo književno i književnometodičko obrazovanje nedostatno zbog čega prednost daju edukativnoj i moralizatorskoj dimenziji djela umjesto umjetničkim svojstvima i užitcima čitanja.

Visinko (2000) je na temelju provedenoga istraživanja prikazala sustav kriterija za uključivanje slikovnice u odgojno-obrazovni proces. U vezi s kriterijem stupnja odgoja i naobrazbe učenika primijetila je da se slikovnica postupno zanemaruje nakon drugoga razreda osnovne škole, a mogla bi se obrađivati i u višim razredima i srednjoj školi: „razlike su u razini interpretacije i načinu bavljenja slikovnicom" (71). Zatim, zagovara uvođenje slikovnice u različite oblike odgojno-obrazovnoga rada i razmatra mjesto slikovnice u pojedinim nastavnim predmetima i unutarpredmetnim područjima Hrvatskoga jezika. Pritom primjećuje da u svojim zapisima učitelji veću pozornost pridaju verbalnomu dijelu slikovnice, što otvara pitanje kako u praksi pristupaju vezi riječi i ilustracija. Osvrnula se na ulogu slikovnica u nastavi početnoga čitanja i pisanja, stvaralaštvo potaknuto slikovnicom, osobni izbor slikovnica te poteškoće u radu sa slikovnicama zbog neopremljenosti školskih knjižnica dostatnim brojem novijih naslova.

$\mathrm{Na}$ rezultate koje donosi Visinko nadovezuje se i istraživanje $\mathrm{M}$. Lazzaricha (2011) o integracijskoj primjeni slikovnice u nastavi Hrvatskoga jezika kojim je utvrdio da korelacijsko-integracijski pristup na primjeru slikovnica poetskoga tipa potiče na čitanje i razumijevanje teksta, bolju interakciju među učenicima te općenito učenici iskazuju zadovoljstvo i pozitivne reakcije na takav 
nastavni sadržaj. Lazzarich (2017: 64) ističe da učitelji u osmišljavanju načina primjene slikovnice $u$ nastavi imaju na raspolaganju različite strategije, metode i oblike rada, a slikovnica je osobito primjeren nastavni sadržaj za povezivanje različitih nastavnih predmeta te metodičku raznovrsnost nastave.

Gabelica i Težak (2019) uočile su neprikladan položaj slikovnice u lektiri, odnosno njezino zanemarivanje od trećega razreda na što je upozorila i Visinko (2000). Gabelica i Težak starijim učenicima namijenile bi slikovnice s više teksta, no količina teksta ne mora biti presudna, dapače postoje bezrječne slikovnice namijenjene djeci i odraslima koje bi također mogle postati dijelom školske lektire. Danas je slikovnica prepoznata kao slojevita umjetnička vrsta i uočena je potreba za slikovničkom lektirom za učenike svih uzrasta ${ }^{7}$.

Narančić Kovač razmotrila je razloge za uključivanje dječje književnosti i slikovnice u nastavu stranoga jezika u osnovnoj školi i podijelila ih je u dvije osnovne skupine. U prvome pristupu one služe razvijanju jezične kompetencije, a u drugom je jezik sredstvo za razvoj književne, pripovjedne, kulturne i međukulturne kompetencije odnosno „odgojnih i obrazovnih ciljeva koji proizlaze iz književnosti kao slojevitoga i jedinstvenoga načina kreativnoga i umjetničkoga izražavanja i prenošenja univerzalnih i kulturno-specifičnih vrijednosti, kao ljudske djelatnosti koja pridonosi razvoju kognitivnih sposobnosti, kritičkoga mišljenja, ali i senzibilnosti za suptilne nijanse značenja i bogatstvo ljudskih čuvstava" (2019a: 344-345). Pritom ističe da je drugi pristup ,višestruko korisniji, a njegovi su učinci slojevitiji i trajniji nego kada se književni tekst svede na razinu nastavnoga materijala za uvježbavanje struktura" (337).

Batič (2019) je, ispitujući gledišta odgojitelja i učitelja razredne nastave u Sloveniji o integraciji slikovnice u proces poučavanja, došla do saznanja da odgojitelji i učitelji uglavnom smatraju kako nemaju poteškoća u odabiru kvalitetnih naslova, međutim u odgovorima na pitanja otvorenoga tipa nije dobila potvrdu za to. Primijetila je i neprimjerenosti u čitanju slikovnica, što se ogleda $u$ nesinkronome čitanju verbalnoga i vizualnoga diskursa (15,8 \% ispitanika djeci ili učenicima ilustracije je pokazalo nakon čitanja jezičnoga dijela teksta) ili neprepoznavanju važnosti prednjih korica u motivaciji djece i učenika za čitanje slikovnice. I ranijim je istraživanjima primijećeno da se peritekstualnim sastavnicama (kao što su korice, ovitak, spojni listovi, naslovna stranica i sl.) često ne pridaje pozornost tijekom čitanja naglas u odgojno-obrazovnim situacijama.

\footnotetext{
${ }^{7}$ Zaključak je to i okrugloga stola održanoga u sklopu Međunarodnoga festivala slikovnica Ovca u kutiji 2017. (Šišović 2017).
} 
Iako su profesionalni posrednici slikovnice skloni previdjeti važnost tih svojstava, mijenjaju svoje stavove nakon osvješćivanja uloge periteksta (Martinez, Stier i Falcon 2016). Batič je uočila i da je likovno izražavanje i stvaralaštvo potaknuto slikovnicom često pogrešno jer se iscrpljuje u pukom kopiranju najdražih motiva i ilustracija.

Iz prethodnoga pregleda dosadašnjih istraživanja o mogućnostima primjene slikovnice u dječjim vrtićima i školi, razvidno je da takva istraživanja nisu brojna, a ona provedena upućuju na to da slikovnica često ima neprimjeren položaj u odgojno-obrazovnome sustavu, primjerice zbog upućivanja slikovnice samo djeci rane i predškolske dobi te mlađim učenicima, neprikladne pripreme odgojitelja ili svođenja slikovnice na razinu didaktičkoga sredstva za ostvarivanje drugih ciljeva.

\section{KORPUS I METODOLOGIJA ISTRAŽIVANJA}

Korpus ovoga istraživanja čine važeći odgojno-obrazovni dokumenti Republike Hrvatske, općega i posebnoga tipa.

Temeljni je opći dokument Nacionalni okvirni kurikulum za predškolski odgoj i obrazovanje te opće obvezno i srednjoškolsko obrazovanje (NOK 2011) kojim su definirane temeljne odgojno-obrazovne vrijednosti, ciljevi odgoja i obrazovanja, kao i načela i ciljevi pojedinih odgojno-obrazovnih područja te dane smjernice za vrednovanje učeničkih postignuća i ostvarivanja kurikula.

Nacionalni kurikulum za rani i predškolski odgoj i obrazovanje (NKRPOO 2015) osnovni je dokument za početnu razinu odgoja i obrazovanja, a u njegovu su središtu vrijednosti, načela i ciljevi, a ne sadržaji.

U ovome radu analiziraju se nastavni programi i kurikuli za Hrvatski jezik, Engleski jezik (prvi strani jezik) za osnovnu školu i gimnazije te Likovna kultura u osnovnoj školi i Likovna umjetnost $u$ gimnazijama. S obzirom na to da je $u$ Hrvatskoj u tijeku obrazovna reforma, u obzir se uzimaju novodoneseni dokumenti i oni koji su djelomično aktualni.

Nastavni plan i program za osnovnu školu (NPPOŠ 2006), nastao na temelju HNOS-a (2005), ove školske godine, 2020./2021., još se primjenjuje u četvrtome i osmome razredu, a nastavni programi za gimnazije koji su bili na snazi od 90-ih godina 20. stoljeća također su važeći još samo ove školske godine u četvrtome razredu.

Korpus obuhvaća spomenute nastavne programe navedenih predmeta za sve razrede, dakle i one koji su izvan uporabe i nove predmetne kurikule (2019) kako bi se mogle usporediti recentne promjene u pristupu slikovnici. 
U korpus su uključeni i popisi izbornih lektirnih djela za osnovnu i srednju školu nastali na temelju rezultata upitnika koji je ispunilo 8344 učitelja razredne nastave, učitelja i nastavnika Hrvatskoga jezika te školskih knjižničara na poziv Ministarstva znanosti i obrazovanja 2019. godine.

U opisanome su korpusu ispitani zastupljenost i položaj slikovnice:

a) s obzirom na odgojno-obrazovna područja odnosno nastavne predmete $\mathrm{i}$ odgojno-obrazovna razdoblja, odnosno razrede

b) s obzirom na predmetna područja/domene, sadržaje, ishode i pristupe

c) u lektiri.

Provedena je kvalitativna i poredbena analiza obrazovnih dokumenata.

\section{REZULTATI I RASPRAVA}

4.1. Zastupljenost slikovnice u dokumentima s obzirom na odgojno-obrazovna razdoblja odnosno razrede u pojedinim odgojno-obrazovnim područjima, odnosno nastavnim predmetima

Analiza dokumenata, kao što se može iščitati iz Tablice 1, pokazala je da se slikovnica izrijekom ne spominje u NKRPOO-u. Iako iz njega nije očigledna važnost slikovnice u ranome i predškolskome odgoju, ona se vjerojatno implicitno podrazumijeva jer mjerila za opremu dječjega vrtića utvrđena Državnim pedagoškim standardom predškolskoga odgoja i naobrazbe (2008, čl. 50) uključuju prostor i opremu za čitanje slikovnica. Iako smatramo da bi slikovnica trebala biti spomenuta i u NKRPOO-u, njezino nespominjanje može se donekle objasniti organizacijom dokumenta koji ne uključuje odgojno-obrazovne sadržaje. U Hrvatskoj, međutim, nedostaju i dodatni materijali za odgojitelje, poput primjerice slovenske publikacije Otrok v vrtcu: priročnik h kurikulu za vrtce (2001) ${ }^{8}$, kojima bi se odgojiteljima osigurala podrška u planiranju i programiranju rada sa slikovnicom u odgojnoj skupini.

NOK (2011) ne izdvaja posebno slikovnicu, već se samo općenito navode književni i neknjiževni tekstovi kao sadržaj za ostvarivanje ciljeva i učeničkih postignuća.

Slikovnica se u programu za Hrvatski jezik (2006) izrijekom spominje samo u prvome razredu, kao zasebna tema, a u kurikulu (2019) se spominje u

\footnotetext{
${ }^{8}$ U priručniku je cijelo poglavlje posvećeno jeziku (na tridesetak str.), a u njemu se nalazi i potpoglavlje Književna vzgoja v vrtcu (petnaestak str.). Slikovnica je posebno izdvojena (str. 99-101) i donose se načela i primjeri.
} 
razradama ishoda i/ili navodi kao sadržaj za ostvarivanje odgojno-obrazovnih ishoda od prvoga do petoga razreda osnovne škole. Za Hrvatski jezik (HJ) može se, prema tome, utvrditi određeni pomak u smislu dobne namjene slikovnice, međutim on je još uvijek nedostatan. Strip se, primjerice, pojavljuje do osmoga razreda u osnovnoj školi i u svim četirima razredima gimnazije, a nema razloga zašto se i slikovnica ne bi obrađivala na višim obrazovnim stupnjevima.

Položaj slikovnice u Engleskome jeziku (EJ) pokazuje da promišljanje o slikovnici i učeničkoj dobi nije bilo sustavno u kurikulnoj reformi. Naime, slikovnica se u novome dokumentu za Engleski jezik s obzirom na dobnu namjenu našla u nepovoljnijemu položaju. Nastavnim programom (2006) bila je uključena u prvih pet razreda osnovne škole, a u kurikulu se eksplicitno spominje samo u prvome razredu. Iako kurikul načelno ostavlja mogućnost uključivanja slikovnice i kasnije ${ }^{9}$, bitno je ekplicitno navesti slikovnicu upravo zbog toga što pogrešna pretpostavka o njezinoj namjeni isključivo mlađim čitateljima može i danas postojati među učiteljima.

Slikovnica je i u likovnome odgoju i obrazovanju (LIK) prisutna samo na početnim obrazovnim razinama, s neznatnim pomakom od pojavnosti u prvome razredu u NPPOŠ-u do uključivanja i u drugi razred osnovne škole u kurikulu.

Slikovnica se u NPPOŠ-u spominje i u poglavlju o školskoj knjižnici, a također se odnosi na prvi razred osnovne škole.

Dakle, slikovnica je u donedavnim i važećim odgojno-obrazovnim dokumentima namijenjena ponajprije početnomu književnom, jezičnom, umjetničkom i informacijskom obrazovanju u školi, a iz nastavnih programa i kurikula u najboljemu slučaju iščezava nakon petoga razreda osnovne škole. Obrazovna reforma propustila je dati slikovnici primjerenije mjesto, odnosno uvesti ju u više odgojno-obrazovne cikluse.

4.2. Zastupljenost slikovnice $u$ dokumentima $s$ obzirom na predmetna područja/domene, nastavne sadržaje, odgojno-obrazovne ishode $i$ pristup slikovnici

Iako se slikovnica u NKRPOO-u ne spominje izrijekom, poneki se zaključci o pristupu slikovnici mogu donijeti na temelju cilja ranoga i predškolskoga odgoja koji se tiče cjelovitoga razvoja odgoja i učenja djece te

${ }^{9}$ Primjerice, u razradi ishoda u trećem razredu piše: ,uspoređuje književne tekstove na engleskom jeziku s onima iz vlastite kulture npr. ilustrirane priče, jednostavne pjesme, stripovi i sl. Otvoreno je pitanje podrazumijeva li se ovdje i slikovnica. 
razvoja njihovih kompetencija. Primjerice, u razvoju jedne od temeljnih kompetencija - komunikacije na materinskome jeziku naglasak se stavlja na produktivne jezične i stvaralačke djelatnosti - govorenje i pisanje, odnosno bilježenje, a ne na recepcijske - slušanje i čitanje odnosno predčitalačke aktivnosti (gledanje ilustracija, listanje knjiga). Međutim, djelatnosti prihvaćanja osobito su važne pri ranome usvajanju jezika (v. u Pavličević-Franić 2005: 90-100), pa i nadređene stvaralačkim djelatnostima na početku književnoga obrazovanja (Blažić 2013: 255-256). Slušanje bi u razvoju kompetencije na materinskome jeziku trebalo biti prepoznato kao i u metodici glazbene kulture za rad u dječjim vrtićima (usp. Gospodnetić 2015, Sam 1998), ali dakako na odgovarajući način kojim se uvažavaju osobitosti jezičnoga i književnoga područja. Štoviše, jasno je da se u dokumentu $\mathrm{u}$ vezi s navedenom kompetencijom nije poštovao slijed jezičnih djelatnosti u čovjekovu životu: slušanje, govorenje, čitanje, pisanje (usp. Visinko 2010: 20).

Nasuprot tomu, rezultati istraživanja stavova odgojitelja u vezi s njihovim kompetencijama za razvoj kompetencija djece ranoga i predškolskoga uzrasta (Dundović, Srića i Karlovčan 2019), pokazuju da većina ispitanika (čak $95 \%$ ) smatra da uglavnom ili u potpunosti posjeduju potrebna znanja i vještine za razvoj dječje kompetencije na materinskome jeziku, a nijedan ispitanik ne smatra da mu je potrebna dodatna podrška za razvoj te kompetencije. Većina je i prepoznala slikovnicu kao poticaj za razvoj kompetencije na materinskome jeziku. Postavlja se pitanje prate li odgojitelji kurikulne smjernice ili je njihova pretjerana sigurnost $\mathrm{i}$ samouvjerenost pokazatelj nedovoljne osviještenosti o važnosti i obuhvatnosti navedene kompetencije koja nadilazi služenje materinskim jezikom te pogrešnih predodžbi o slikovnici.

Slikovnica u ranome i predškolskome odgoju može imati važnu ulogu u razvoju kompetencije kulturne svijesti i izražavanja, koja obuhvaća recepcijsku i produktivnu razinu, što je razvidno već iz naziva kompetencije.

U Tablici 2. popisani su određeni dijelovi iz Nastavnoga plana i programa za osnovnu školu te predmetnih kurikula koji se odnose na slikovnicu. Iz NPPOŠ-a doslovno su preuzete formulacije, osim za područje dječje književnosti za Engleski jezik koje su neprikladne za tablični prikaz zbog opširnosti, ali se analiziraju u tekstu. Ishodi iz kurikula doslovno su preneseni u Tablicu, a u tekstu se na njih upućuje odgovarajućom oznakom (pri čemu se slovo, nakon kratice OŠ i naziva predmeta, odnosi na domenu, prva brojka označava razred, a druga broj ishoda pojedine domene). Razrade ishoda i sadržaji, odnosno preporuke za ostvarivanje ishoda nisu uključeni u Tablicu zbog obima. 
Slikovnica se u školskim reformskim dokumentima, neočekivano, ne naglašava kao sadržaj za ostvarivanje ishoda $u$ domeni A. Hrvatski jezik i komunikacija nastavnoga predmeta Hrvatskoga jezika. U predmetu Engleski jezik u domeni A. Komunikacijska jezična kompetencija slikovnica se također ne spominje izrijekom, ali ne može se isključiti da je obuhvaćena dječjom književnosti koja se navodi do petoga razreda, a potom se dopunjuje (šesti razred), odnosno zamjenjuje (sedmi i osmi razred) književnosti za mladež. Za razliku od toga, slikovnica je u ranijemu nastavnom programu za osnovnu školu za Engleski jezik bila posebno istaknuta za razvoj vještine govorenja u trećemu i četvrtome razredu i to $u$ vezi s povezivanjem elemenata priče.

Položaj slikovnice u području književnosti u školskim dokumentima nije moguće jednoznačno odrediti. U kurikulu Hrvatskoga jezika (2019) u domeni B. Književnost i stvaralaštvo slikovnica je zastupljenija nego u ranijemu programu (2006), međutim raščlambom ishoda po razredima pokazuje se da se upoznavanje slikovnice kao posebne vrste iscrpljuje u trećemu razredu osnovne škole. Razradama ishoda OŠ HJ B.1.3., OŠ HJ B.2.2., OŠ HJ B.2.3. i OŠ HJ B.3.3. pretpostavlja se razlikovanje slikovnice i njezinih vrsta. Dokument, međutim, ostaje neodređen $\mathrm{u}$ pogledu različitih vrsta slikovnica koje bi učenici trebali upoznati, pri čemu je razrada ishoda OŠ HJ B.2.2. svojevrsna iznimka jer navodi da učenik razlikuje slikovnicu po obliku i sadržaju. Ipak, i takvo određenje ostavlja prostora za različita tumačenja. Prema jednoj od mogućih tipologija, one Diane Zalar (2012: 84), po formi se razlikuju leporello, pop-up, nepoderive, slikovnice igračke i multimedijske slikovnice, a po sadržaju slikovnice o slovima, životinjama, svakodnevnom životu, igrama, fantastične i dr. slikovnice, no što se u kurikulu smatra oblikom i sadržajem nije poznato. U Nastavnome planu i programu (2006) školskoj knjižnici bilo je posvećeno posebno poglavlje, pa joj je bio povjeren jedan od zadataka, razlikovanje slikovnica od knjiga (sic!) i rječnika. S obzirom na to da nema posebnoga nacionalnog kurikula za školsku knjižnicu, u kurikulu Hrvatskoga jezika uspostavljena je prikladna korelacija pa se u razradama ishoda OŠ HJ B.1.3. i OŠ HJ B.2.3. navodi da učenik posjećuje školsku knjižnicu i posuđuje slikovnice te ih preporučuje drugim učenicima i objašnjava svoj izbor. U kasnijemu razredu, međutim, slikovnica je primjerice kao sadržaj povezana s ostvarivanjem ishoda (OŠ HJ B.3.2. koji se odnosi na određivanje obilježja književnoga teksta, kao što su: tema, redoslijed događaja, mjesto i vrijeme radnje, lik i dr.), ali je navedena kao jedan od devet predloženih sadržaja pa se tek proučavanjem prakse mogu dobiti konkretni podaci o njezinoj stvarnoj zastupljenosti. U kurikulu Hrvatskoga jezika bilježi se pojava slikovnice u petome 
razredu, a ona se odnosi na stvaralaštvo učenika koji crta slikovnicu. Podatak sam po sebi i nije informativan jer može imati različite izvedbe, a svrhu bi ostvario kad bi učenici u toj aktivnosti primijenili spoznaje o slikovnici kao sintetskoj umjetničkoj vrsti i njezinim (pod)vrstama. Uopće, razrada ishoda koja se odnosi na različite vrste slikovnica ima potencijala za podrobniju i svrhovitiju razradbu te uvođenje u više razrede osnovne škole pa i srednju školu. Podrobne upute za odabir i uporabu slikovnice po razredima u skladu s načelom postupnosti te prirodom i svrhom nastavnoga predmeta dane su u nastavnome programu za Engleski jezik (2006) u kojem se slikovnica kao nastavni sadržaj navodi u obrazovnim postignućima za Kulturu i civilizaciju, u zasebnome dijelu dječja književnost, od prvoga do petoga razreda. U prvome i drugome razredu poraba je slikovnice na razini preporuke, a kasnije se obradba propisuje. Broj naslova varira od jednog do dvaju. Odabir naslova prepušten je učiteljima. U prvim trima razredima ističe se i obradba ili čitanje na satu te kvaliteta ilustracija i privlačan dizajn slikovnica kao i da je slikovnica izvorna. Posebne upute odnose se i na tekst i priču: u prvim trima razredima slikovnica treba sadržavati malo teksta, odnosno tekst koji se ponavlja, a od drugoga razreda uvodi se uvjet da barem jedna slikovnica bude pripovjedna (da sadrži priču). Kako učenici napreduju u poznavanju stranoga jezika, otvara se mogućnost i samostalnoga čitanja slikovnica s nepoznatom pričom za pojedine učenike u četvrtome i petome razredu. Takve jasne i razrađene upute napuštene su u kurikulu za Engleski jezik (2019), a u njemu se slikovnica eksplicitno pojavljuje samo u prvome razredu osnovne škole u razradi ishoda u domeni B. Međukulturna jezična kompetencija, prema kojemu učenici prepoznaju i pozitivno reagiraju na različite književne tekstove, uključujući slikovnice.

Pojavnost slikovnice u području kulture i međukulturnosti u predmetnim kurikulima Hrvatskoga i Engleskoga jezika opravdana je i poželjna, ali nedovoljno razvijena. U predmetnome kurikulu Hrvatskoga jezika eksplicitno se pojavljuje također samo u prvome razredu osnovne škole, u vezi s ishodom OŠ C.1.2., i odnosi se više na slikovnicu kao medij, odnosno drugi dio domene u koju je uključena kultura, prema čijoj razradi učenik izdvaja slikovnice kao primjerene medijske sadržaje i razgovara o njima. Posredno je slikovnica uključena i u ishode u četirima nižim razredima osnovne škole koji se odnose na posjećivanje kulturnih događaja (OŠ HJ C.1.3., OŠ HJ C.2.3., OŠ HJ C.3.3. i OŠ HJ C.4.3.), a podrazumijevaju susrete $\mathrm{s}$ ilustratorima. Iako se susreti s ilustratorima u pravilu ograničavaju na lokalne ili nacionalne umjetnike, a zahvaljujući internetskomu okruženju ponekad se mogu uspostaviti i kontakti s međunarodnim ilustratorima, u susretima s njima naglasak se ne mora staviti na razvijanje kulturne i međukulturne 
kompetencije. Prema tome, u predmetnim kurikulima materinskoga i stranoga jezika kulturni kontekst i međukulturni pristup u susretu sa slikovnicom potrebno je uvažiti i naglasiti i poslije prvoga razreda, produbiti ih $i$ uspostaviti međupredmetnu korelaciju i integraciju. Razvoj međukulturne kompetencije pomoću slikovnice potiče se i u predmetu Likovne kulture ishodom OŠ LK C.1.2. No, iako je svrha domene C. Umjetnost u kontekstu, između ostaloga, poticati učenike na uvažavanje kulturnih raznolikosti, u razradi navedenoga ishoda povezivanje aspekata umjetničkoga djela ograničava se na učeničko svakodnevno iskustvo i njegovu okolinu. To doduše korelira s ishodom OŠ HJ B.3.1., ali u razvoju kulturne i međukulturne kompetencije valjalo bi uvažiti i iskustva iz udaljenijih kultura s kojima se učenik nema priliku susresti u neposrednoj okolini. Dakako, to bi se moglo postići produbljivanjem ishoda i upućivanjem na slikovnicu u višim razredima, što izostaje i u kurikulu Likovne kulture.

Kao što je spomenuto, slikovnica se u kurikulu Hrvatskoga jezika pojavljuje i u okviru stvaralaštva koje je s književnosti povezano u jednu domenu. Stvaralaštvo je, međutim, iznimno bitna sastavnica likovnoga odgoja i obrazovanja. U nastavnome programu za Likovnu kulturu (2006) slikovnica se navodi kao ključni pojam u vezi s obrazovnim postignućem likovnoga izražavanja doživljaja priče. Iako se u kurikulu ponajprije javlja u domeni C. Umjetnost u kontekstu, njome se upućuje i na domenu A. Stvaralaštvo i produktivnost, ishodom OŠ LK C.2.1. Učenik tako „likovnim izražavanjem i kreativnom igrom [...] uspoređuje odnose slika i teksta" u slikovnicama kao njemu bliskim tiskovinama. Takav ishod zapravo bi predstavljao vrlo primjereno produbljivanje obrazovnih postignuća o slikovnici iz prvoga razreda, iz književnosti kao nastavnoga područja Hrvatskoga jezika, koja su bila predviđena ranijim dokumentom: „spoznati i doživjeti (recepcija) kratke slikovnice, stilski i sadržajno primjerene djetetu; razlikovati slikovnicu od drugih knjiga zbog povezanosti slike i teksta" (NPPOŠ: 27). U kurikulu Hrvatskoga jezika, nažalost, izostavljena je takva differentia specifica slikovnice. Valja primijetiti i da recepcija slikovnice nije prikladno prepoznata $u$ kurikulu Likovne kulture, odnosno nije uključena u domenu B. Doživljaj i kritički stav čiji je cilj sustavno odgajanje opažaja. Ipak, ne može se poreći da kurikul ostavlja takvu mogućnost jer su domene zamišljene kao komplementarne i međusobno povezane, već je glavna poteškoća kurikula njegova uopćenost i nedovoljna određenost pa se u konkretizaciji kurikula lako mogu izgubiti beskrajne pretpostavljene korelacijske mogućnosti. 


\subsection{Položaj slikovnice u lektiri}

Lektira se i u Nastavnome planu i programu (2006) i predmetnim kurikulima (2019) pojavljuje jedino u okviru Hrvatskoga jezika. U nastavnome programu za Hrvatski jezik (2006) donose se popisi lektire po razredima, pri čemu se navodi koji su naslovi obvezni i broj naslova koje treba odabrati s popisa. Slikovnički naslovi nalaze se samo na popisima za prvi i drugi razred, na što su upozorile Gabelica i Težak (2019), ali oni nisu među obveznim naslovima. Zatim, konačan popis učiteljima nije ostavljao mogućnost odabira recentnoga slikovničkog naslova. Kurikulom (2019) je učiteljima i nastavnicima povjerena veća sloboda u odabiru naslova premda se i u njemu donosi popis obveznih književnih djela za cjelovito čitanje. Iako kurikul preporuča suvremene naslove, upitnikom upućenim učiteljima, nastavnicima i stručnim suradnicima knjižničarima utvrđeno je da u praksi nema velikoga interesa za suvremene slikovnice i da se prednost daje djelima koja su već bila u lektiri. Na popisu izbornih djela za lektiru nastaloga na temelju rezultata upitnika među prvih trinaest djela po broju glasova za prvi i drugi razred osnovne škole, odnosno među djelima s 1000 ili više glasova, nema nijednoga naslova koji nije bio na prošlome popisu (2006). Nasuprot tomu, primjerice, višestruko nagrađivana slikovnica Velika tvornica riječi A. de Lestrade i V. Docampo, objavljena 2009. u izvorniku, a 2013. u hrvatskome prijevodu, dobila je svega 13 glasova. Nekoliko desetaka ili manje glasova dobile su i druge svjetski poznate ili popularne slikovnice, kao što su Najotmjeniji div u gradu (35) i Grubzon (31) J. Donaldson i A. Schefflera i Fantastične leteće knjige g. Morrisa Lessmorea W. Joycea i J. Bluhma (26; ali i 21 glas kao djelo na popisu za treći, četvrti i peti razred).

Osim toga, u lektirnim popisima ne navode se ilustratori neautorskih slikovnica, a neki su učitelji stoga protumačili i da se umjesto određenih naslova (npr. Collodijeva Pinokija u drugome razredu) omogućava obradba njihovih slikovničkih adaptacija, kao što pokazuju pojedini primjeri iz nastavne prakse. Također, u skladu s nepreciznim popisom bilježi se i pojava čitanja različitih slikovničkih adaptacija $\mathrm{u}$ istome razrednom odjelu (primjerice Torjančeva i Junakovićeva slikovnička adaptacija pjesme Kako živi Antuntun G. Viteza), ovisno o dostupnosti naslova u školskoj knjižnici. Dakako, to nije problematično samo po sebi, već isključivo ako se zanemari vizualna sastavnica i izostane poredbeni pristup dvjema različitim adaptacijama. 
Proizlazi da su lektirni popisi zapravo sporedni u odnosu na svrhu i ciljeve lektire (usp. Narančić Kovač 2019b). Slikovnica u hrvatskim obrazovnim dokumentima nije prepoznata kao posebna umjetnička vrsta u lektiri odnosno nije istaknut osobit cilj slikovničke lektire, poput primjerice razvijanja vizualne pismenosti, čime bi joj se osigurao povoljniji položaj.

Zatim, obrazovnom reformom nije uvažena ili prepoznata potreba za neknjiževnom lektirom (usp. Visinko 2003) ili uključivanjem lektire u druge nastavne predmete (usp. Jerkin 2012), pa se tako ne spominju nefiktivne ili informativne slikovnice $\mathrm{u}$ kontekstu lektire u drugim predmetima ili međupredmetne korelacije.

\section{ZAKLJUČAK}

Odgojno-obrazovni dokumenti u ovome radu istražili su se kao pokazatelji položaja slikovnice u hrvatskome odgojno-obrazovnom sustavu, ponajviše u okviru književnoga odgoja. Analizom dokumenata s obzirom na prisutnost slikovnice u određenim odgojno-obrazovnim područjima i nastavnim predmetima na pojedinim obrazovnim razinama dobiveni su ambivalentni rezultati.

U najranijemu razdoblju, ranome i predškolskome odgoju, slikovnici zasigurno pripada važno mjesto, no u odgovarajućemu aktualnom dokumentu njezina je uloga samo posredno naznačena i to ne posve precizno i prikladno. Naime, zanemarena je recepcijska razina, a prenaglašena stvaralačka. Precizniju sliku o položaju slikovnice u dječjemu vrtiću omogućit će dodatna istraživanja u samim ustanovama, od analize fonda slikovnica do promatranja prakse i refleksija odgojitelja. Pritom bi bilo potrebno provjeriti vide li odgojitelji slikovnicu ponajprije kao odgojno sredstvo i/ili sredstvo za poticanje komunikacijske kompetencije, a koliko uvažavaju njezinu estetsku dimenziju.

$\mathrm{U}$ aktualnim školskim dokumentima slikovnica je najzastupljenija u Hrvatskome jeziku, no nominalna prisutnost ne osigurava i stvarnu jer je slikovnica uglavnom tek preporučeni sadržaj (predložak) uz druge vrste, a njezin unutarpredmetni i međupredmetni korelacijsko-integracijski potencijal također nije posebno istaknut nego se načelno pretpostavlja općim smjernicama. Ograničenja ovoga istraživanja proizlaze, dakle, prije svega iz činjenice da je općenitim kurikulnim preporukama učiteljima prepuštena velika sloboda, stoga je buduća istraživanja položaja slikovnice u nastavi potrebno usmjeriti prema odgojno-obrazovnoj praksi. 
Ipak, odgojno-obrazovni dokumenti dostatni su za utvrđivanje neprikladnoga odnosa prema slikovnici u barem jednome segmentu. Namjenjuju je isključivo mlađim učenicima zanemarujući činjenicu da je ona kao umjetnička vrsta upućena i dječjoj i odrasloj publici. Slikovnicu bi svakako trebalo uključiti u više razrede osnovne škole i u srednju školu, zbog čega je nužno omogućiti odgovarajuće slikovničko obrazovanje na fakultetskoj razini, osim budućim odgojiteljima i učiteljima razredne nastave, i budućim učiteljima predmetne nastave, nastavnicima te knjižničarima.

Potrebno je također odgojno-obrazovnim djelatnicima i knjižničarima kontinuirano pružati odgovarajuću podršku u obliku stručnih skupova i programa cjeloživotnoga obrazovanja kako bi bili upoznati s novim znanstvenim spoznajama $u$ vezi sa slikovnicom, kritičkim ocjenama novih naslova i suvremenim metodičkim mogućnostima.

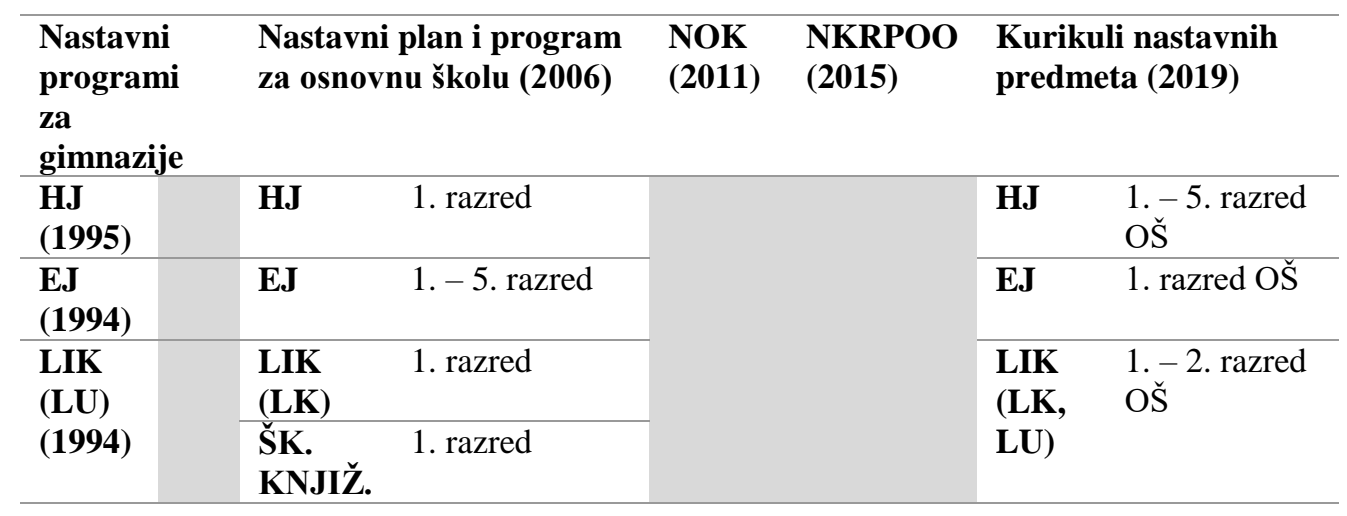

Tablica 1. Pojavnost slikovnice u odgojno-obrazovnim dokumentima po odgojnoobrazovnim ciklusima odnosno razredima u pojedinim odgojno-obrazovnim područjima, odnosno nastavnim predmetima 


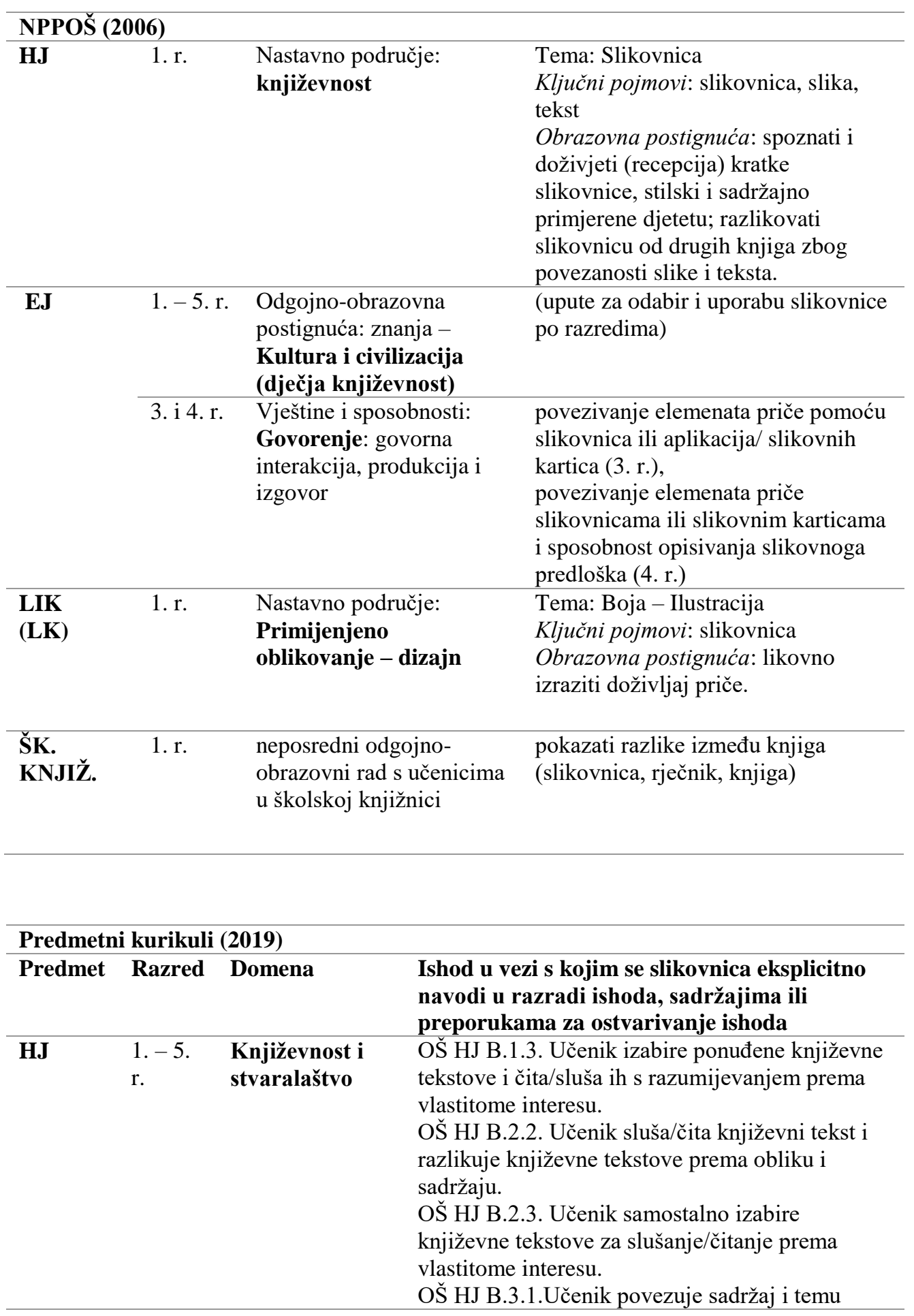


književnoga teksta s vlastitim iskustvom.

OŠ HJ B.3.2. Učenik čita književni tekst i uočava pojedinosti književnoga jezika.

OŠ HJ B.3.3. Učenik čita prema vlastitome interesu te razlikuje vrste knjiga za djecu.

OŠ HJ B.3.4. i OŠ HJ B.5.4. Učenik se stvaralački izražava prema vlastitome interesu potaknut različitim iskustvima i doživljajima književnoga teksta.

OŠ HJ B.4.1. Učenik izražava doživljaj književnoga teksta u skladu s vlastitim čitateljskim iskustvom.

\begin{tabular}{|c|c|c|c|}
\hline & 1. $\mathrm{r}$. & $\begin{array}{l}\text { Kultura i } \\
\text { mediji }\end{array}$ & $\begin{array}{l}\text { OŠ C.1.2. Učenik razlikuje medijske sadržaje } \\
\text { primjerene dobi i interesu. }\end{array}$ \\
\hline EJ & 1. r. & $\begin{array}{l}\text { Međukulturna } \\
\text { komunikacijska } \\
\text { kompetencija }\end{array}$ & $\begin{array}{l}\text { OŠ EJ B.1.1. Uočava međukulturna iskustva u } \\
\text { poznatome kontekstu te prepoznaje osnovne } \\
\text { činjenice i obilježja kultura ciljnoga jezika ili } \\
\text { drugih kultura i uočava sličnosti s vlastitom } \\
\text { kulturom. }\end{array}$ \\
\hline \multirow[t]{2}{*}{$\begin{array}{l}\text { LIK } \\
\text { (LK) }\end{array}$} & 1. r. & $\begin{array}{l}\text { Umjetnost u } \\
\text { kontekstu }\end{array}$ & $\begin{array}{l}\text { OŠ LK C.1.2. Učenik povezuje neki aspekt } \\
\text { umjetničkog djela s iskustvima iz svakodnevnog } \\
\text { života te društvenim kontekstom. }\end{array}$ \\
\hline & 2.r. & $\begin{array}{l}\text { Umjetnost u } \\
\text { kontekstu } \\
\text { (i Stvaralaštvo i } \\
\text { produktivnost) }\end{array}$ & $\begin{array}{l}\text { OŠ LK C.2.1. Učenik prepoznaje i u likovnom ili } \\
\text { vizualnom radu interpretira povezanost } \\
\text { oblikovanja vizualne okoline s aktivnostima i } \\
\text { namjenama koje se u njoj odvijaju. (Ishod se } \\
\text { ostvaruje zajedno s ishodom A.2.1. Učenik } \\
\text { likovnim i vizualnim izražavanjem interpretira } \\
\text { različite sadržaje.) }\end{array}$ \\
\hline
\end{tabular}

Tablica 2. Zastupljenost slikovnice u Nastavnome planu i programu (2006) i predmetnim kurikulima (2019) u pojedinim područjima, odnosno domenama nastavnih predmeta

\section{IZVORI}

Državni pedagoški standard predškolskog odgoja i naobrazbe (2008). Narodne novine 63.

Izborna djela za lektiru - 1. i 2. razred osnovne škole (2019). Dostupno na <http://mzo.gov.hr> (pretraživanjem po dokumentima).

Izborna djela za lektiru - 3., 4. i 5. razred osnovne škole (2019). Dostupno na $<$ http://mzo.gov.hr> (pretraživanjem po dokumentima).

Kurikulum nastavnog predmeta Engleski jezik za osnovne škole i gimnazije (2019). Narodne novine 7.

Kurikulum nastavnog predmeta Hrvatski jezik za osnovne škole i gimnazije (2019). Narodne novine 10. 
Kurikulum nastavnog predmeta Likovna kultura za osnovne škole i Likovna umjetnost za gimnazije (2019). Narodne novine 7.

Nacionalni kurikulum za rani i predškolski odgoj i obrazovanje (2015). Narodne novine 5.

Nacionalni okvirni kurikulum za predškolski odgoj i obrazovanje te opće obvezno i srednjoškolsko obrazovanje (2011). Zagreb: Ministarstvo znanosti, obrazovanja i športa.

Nastavni plan i program za osnovnu školu (2006). Zagreb: Ministarstvo znanosti, obrazovanja i športa.

Nastavni programi za gimnazije. Hrvatski jezik za gimnazije (1995). Zagreb: Glasnik Ministarstva prosvjete i športa.

Nastavni programi za gimnazije. Likovna umjetnost (1994). Zagreb: Glasnik Ministarstva kulture i prosvjete.

Nastavni programi za gimnazije. Strani jezici. Prvi strani jezik: Engleski jezik (1994). Zagreb: Glasnik Ministarstva kulture i prosvjete.

Otrok v vrtcu: priročnik h kurikulu za vrtce (2001). Maribor: Obzorja.

Vodič kroz Hrvatski nacionalni obrazovni standard za osnovnu školu (2005). Zagreb: Ministarstvo znanosti, obrazovanja i športa.

\section{LITERATURA}

Bačić-Karković, D., Car-Mihec, A. (2000). Uvod u genologiju. Rijeka: Filozofski fakultet.

Batič, J. (2019). Reading Picture Books in Preschool and Lower Grades of Primary School. Center for Educational Policy Studies Journal. Pristupljeno 15. 3. 2021. URL <https://doi.org/10.26529/cepsj.554>.

Beckett, S. (2012). Crossover Picturebooks: A Genre for All Ages. New York: Routledge.

Blažić, M. M. (2013). Poučavanje dječje književnosti u predškolskim ustanovama i osnovnoj školi u Sloveniji, u Kurikul ranog učenja hrvatskoga/materinskoga jezika, ur. A. Bežen, B. Majhut (Zagreb: Učiteljski fakultet Sveučilišta u Zagrebu, Europski centar za sustavna i napredna istraživanja): 249-258.

Bukvić, A. (2019). Srušimo zidove: slikovnice za odrasle, slikovnice za sve. Pristupljeno 15. 3. 2021. URL: <https://gkr.hr/Magazin/Prikazi/Srusimozidove-Slikovnice-za-odrasle-slikovnice-za-sve>.

Colomer, T., Kümmerling-Meibauer, B., Silva-Díaz, C. (2010). Introduction: Current trends in Picturebook Research, in New Directions in Picturebook 
Research, eds. T. Colomer, B. Kümmerling-Meibauer i C. Silva-Díaz (New York i London: Routledge): 1-8.

Dundović, N., Srića, S., Karlovčan, A. (2019). Iskustva i stavovi odgojitelja o razvoju kompetencija kod djece ranoga i predškolskoga uzrasta, u Zajedno rastemo - kompetencije djeteta za cjeloživotno učenje: zbornik radova sa stručno-znanstvenog skupa, ur. A. Višnjić Jevtić (Zagreb, Čakovec: Učiteljski fakultet Sveučilišta u Zagrebu, Dječji vrtić „Cvrčak” Čakovec): 29-37.

Gabelica, M., Težak, D. (2019). Kreativni pristup lektiri. Zagreb: Naklada Ljevak. Gospodnetić, H. (2015). Metodika glazbene kulture za rad u dječjim vrtićima. Zagreb: Mali profesor.

Haramija, D. (2004). Pomen knjige za predšolskega otroka, u Književnost i odgoj: zbornik, ur. R. Javor (Zagreb: Knjižnice grada Zagreba): 70-76.

Hateley. E. (2018). Canon processes and picturebooks, in The Routledge Companion to Picturebooks, ur. B. Kümmerling-Meibauer (London i New York: Routledge): 128-136.

Jerkin, C. (2012). Lektira našeg doba. Život i škola 58 (27): 113-133.

Lazzarich, M. (2011). Integracijske mogućnosti slikovnice u nastavi materinskoga jezika. Život $i$ škola 26: 61-81.

Lazzarich, M. (2017). Metodika Hrvatskoga jezika u razrednoj nastavi. Rijeka: Učiteljski fakultet Sveučilišta u Rijeci.

Martinez, M., Stier, C., Falcon, L. (2016). Judging a Book by Its Cover: An Investigation of Peritextual Features in Caldecott Award Books. Children's Literature in Education 47: 225-241.

Martinović, I. (2011). Slikovnica kao poticajni materijal za leksički razvoj u trećoj godini života. Doktorska disertacija. Osijek: Filozofski fakultet.

Martinović, I., Stričević, I. (2013). Kompetencije dječjih knjižničara: koliko poznaju literaturu za svoje korisnike. Vjesnik bibliotekara Hrvatske 56 (3): 67-90.

Narančić Kovač, S. (2012). Slučaj dječje književnosti, u Peti hrvatski slavistički kongres: zbornik radova. Knj. 2, ur. M. Turk, I. Srdoč-Konestra (Rijeka: Filozofski fakultet Sveučilišta u Rijeci): 643-651.

Narančić Kovač, S. (2015). Jedna priča - dva pripovjedača: slikovnica kao pripovijed. Zagreb: ArTresor naklada.

Narančić Kovač, S. (2019a) Dječja književnost i slikovnica u nastavi stranoga jezika, u Izazovi učenja stranoga jezika u osnovnoj školi, ur. Y. Vrhovec i dr. (Zagreb: Naklada Ljevak): 336-357. 
Narančić Kovač, S. (2019b). Stručnjakinja za dječju književnost: I povjerenje i odgovornost učiteljima za uspjeh lektire. Pristupljeno 15. 3. 2021. URL: <https://www.jutarnji.hr/vijesti/hrvatska/strucnjakinja-za-djecju-knjizevnost-ipovjerenje-i-odgovornost-uciteljima-za-uspjeh-lektire-8414804>.

Narančić Kovač, S. (2020) Courses on Children's Literature in Tertiary Education: Focus on Croatia. International Online Conference Fostering Dialogue. Teaching Children's Literature at University. Università degli studi di Padova, November 19-21. (izlaganje)

Neira-Piñeiro, M. R., Martín-Macho Harrison, A. (2020). Los futuros maestros de infantil ante la educación literaria: Análisis de sus creencias sobre la literatura infantil. Revista de currículum y formación del profesorado 24 (2): 224-250. DOI: 10.19090/MV.2021.12.- 10.30827/profesorado.v24i2. 14076

Nikolajeva, M. (2002). The Verbal and the Visual: The Picturebook as a Medium, in Children's Literature as Communication, ed. R. D. Sell (Amsterdam i Philadelphia: John Benjamins Publishing Company): 85-110.

Pavličević-Franić, D. (2005). Komunikacijom do gramatike - razvoj komunikacijske kompetencije u ranome razdoblju usvajanja jezika. Zagreb: Alfa.

Rosandić, D. (2010). Umjesto znanstvenih informacija - uopćene preporuke: jezično-komunikacijsko područje u Nacionalnom okvirnom kurikulumu. Školske novine 15 (13. travnja): 11.

Sam, R. (1998). Glazbeni doživljaj u odgoju djeteta. Rijeka: Glosa.

Shavit, Z. (1994). Beyond the Restrictive Frameworks of the Past: Semiotics of Children's Literature - A New Perspective for the Study of the Field, in Kinderliteratur im interkulturellen Prozeß: Studien zur Allgemeinen und vergleichenden Kinderliteraturwissenschaft, hrsg. H.-H. Ewers, G. Lehnert, E. O’Sullivan (Sttutgart/Weimar: J. B. Metzler ): 3-15.

Skladany, V. (2018). Važnost čitanja i pripovijedanja u radu s djecom rane i predškolske dobi iz perspektive odgajatelja. Završni rad. Rijeka: Učiteljski fakultet u Rijeci.

Slikovnica prva knjiga djeteta. 1972. Umjetnost i dijete - poseban otisak 4 (19/20).

Slunjski, E. (2006). Tradicionalni i suvremeni metodički pristup književnim sadržajima u vrtiću. Učitelj 6: 133-141.

Šišović, D. (2017). Slikovnice uvesti u lektiru za sve uzraste. Pristupljeno 15. 3. 2021. URL: <https://glasistrenovine.hr/arhiva-portala/pregled-vijesti/slikovniceuvesti-u-lektiru-za-sve-uzraste-554186>. 
Thacker, D. (2000). Disdain or Ignorance? Literary Theory and the Absence of Children's Literature. The Lion and the Unicorn 24 (1): 1-17.

Velički, V. (2009). Poticanje govora u kontekstu zadovoljenja dječjih potreba u suvremenom dječjem vrtiću. Metodika: časopis za teoriju $i$ praksu metodikâ u predškolskom odgoju, školskoj i visokoškolskoj izobrazbi 10 (18): 80-91.

Verdonik, M., Štiglić, P. (2015). Pojavnost igrokaza u zbornicima i antologijama dječje književnosti - prinos usustavljivanju književne vrste. Detinjstvo: časopis o književnosti za decu 41 (1): 84-91.

Visinko, K. (2000). Primjena slikovnice u odgojnoj i nastavnoj praksi, u Kakva je knjiga slikovnica, ur. R. Javor (Zagreb: Knjižnice grada Zagreba, Hrvatski centar za dječju knjigu): 70-78.

Visinko, K. (2003). Neknjiževna lektira u osnovnoj školi. Hrčak 17: 20-24.

Visinko, K. (2010). Jezično izražavanje u nastavi Hrvatskoga jezika: pisanje. Zagreb: Školska knjiga.

Zalar, D. (2012). Slikovnica, u Hrvatska književna enciklopedija. Sv. 4, S -Ž., ur. V. Visković (Zagreb: Leksikografski zavod Miroslav Krleža): 84-85.

Corinna Jerkin

University of Zagreb

Faculty of Humanities and Social Sciencies

Maja Opašić

University of Rijeka

Faculty of Teacher Education

THE CASE OF PICTUREBOOK:

PICTUREBOOK PRESENCE IN CROATIAN EDUCATIONAL DOCUMENTS

\section{Summary}

On the basis of the case of children's literature, which points to its concealment and neglect within the literary theory and academic community as a whole, the paper develops and examines picturebooks in the educational context. The case of picturebooks refers to an inferior and inappropriate position picturebooks have in a certain context, such as the educational one, and is based on marginalization of picturebooks as a form strictly intended to the youngest audience. After an insight into the previous research on possibilities to implement picturebooks into kindergartens and schools, it is evident such research is scarce, and the ones that have been carried out imply the inappropriate position picturebooks have in educational system. The aim of this research is therefore to inspect if contemporary theoretical findings on picturebooks are accepted and applied in 
recommendations referring to picturebooks in the process of upbringing, learning and teaching, if they are being neglected within educational documents due to the lack of knowledge or if they are less important than some other elements (contents, goals). Current educational documents in Croatia are analyzed and compared to those in force until recently to determine the presence of picturebooks by educational cycle or grade. Furthermore, the representation of picturebook content in educational areas and subjects, particularly in the subject Croatian Language and especially in required reading lists, is analyzed, including the approaches to picturebooks within particular educational areas. The results indicate that the potential of picturebooks remains unrecognized even in the reform documents, as indicated by contemporary theoretical and pedagogical considerations. Picturebooks remain present mainly at the initial educational levels, while optional and overly generalized guidelines for their introduction into the teaching practice do not ensure their genuine representation and sufficient and standardized deepening of knowledge. This research is limited by the fact that general curriculum recommendations present teachers with a lot of choice and liberty, thus implying that future research on the position of picturebooks in class should be directed at educational practice.

Key words: children's literature, English Language, Croatian Language, curriculum, Arts, syllabus, (early) literary education, picturebook.

Primljeno: 19. 5. 2021.

Prihvaćeno: 4. 7. 2021. 